\title{
Implementation of the Parenting Model to Improve Understanding of Reproduction Health of Vocational High School Students
}

\author{
Merri Sri Hartati \\ Student of Post-Graduate Educational Sciences, Yogyakarta State University, Indonesia, \\ merri.sri2015@student.uny.ac.id
}

\section{IGP Suryadarma}

Prof. Dr., Yogyakarta State University, Indonesia, samodhaya@yahoo.com

\section{Farida Hanum}

Prof. Dr., Yogyakarta State University, Indonesia, faridahanum@uny.ac.id

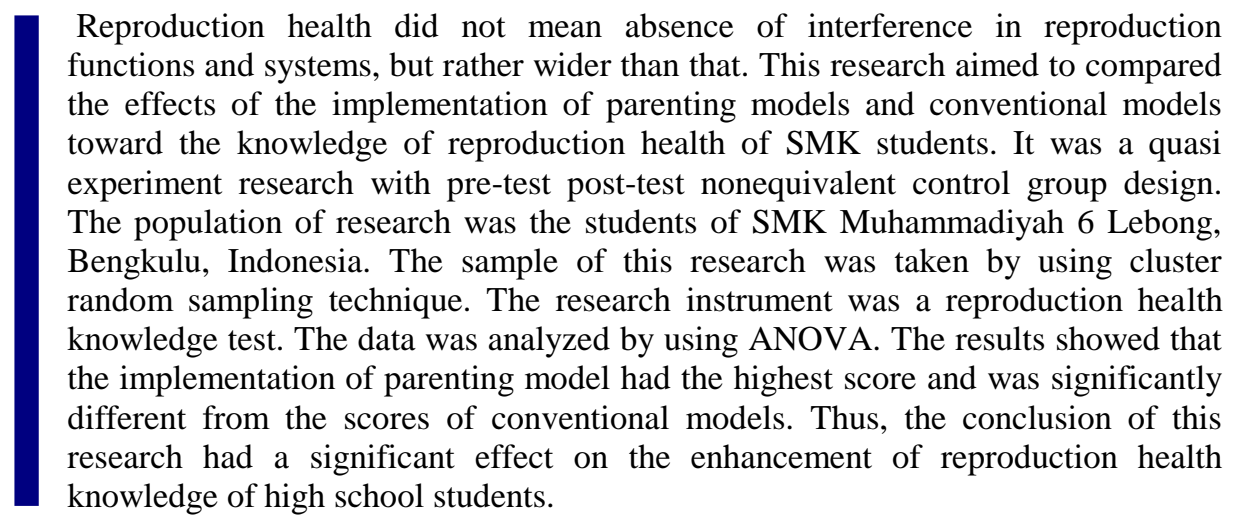

Keywords: parenting education, reproduction health, sexual education, adolescent growth, pregnancy, infectious diseases

\section{INTRODUCTION}

The reproduction process has strated from marriage then conception, pregnancy, childbirth to productive age and old age. Reproduction was a biological process of an individual newly produced organism (Irianto, 2015) aimed at preserving the generation of species, by producing the same offspring as the parent generation (Jacob, 2006). It was showed that reproduction health starts from teenager to old age (Muhammad, 1996)

Citation: Hartati, M. S., Suryadarma, IGP, \& Hanum, F. (2020). Implementation of the Parenting Model to Improve Understanding of Reproduction Health of Vocational High School Students. International Journal of Instruction, 13(1), 215-224. https://doi.org/10.29333/iji.2020.13114a 
According to ICPD (International Conference on Population and Development) (1994), reproduction health care was defined as "a constellation of methods, techniques and services that contribute to reproduction health and well-being by preventing and resolving reproduction health problems. Reproduction health was not only the absence of interference in reproduction functions and systems. More than that, reproduction health also related to the physical, mental and social responses as a whole in all matters relating to the reproduction system, its functions and processes. So that each individual can enjoy safe and enjoyable reproduction health. Denno at al., (2014) teenager was often considered a period of relatively good health. However, teenager (ages 10-19 years) face certain health risks, especially those related to reproduction and sexuality (William, 2014).

Adolescence provided an important phase of life to utilized potential and resourced in this age group. Access to teenager health services is very important to ensure teenager sexual and reproduction health. Morris \& Rushwan, (2015) poor reproduction health was a burden of problems globally. Although many international institutions has working to improve people's reproduction health. Reproduction health, especially teenagers, was strongly related to their social, cultural and sexual orientation. This was supported by Haberland \& Rogow (2015) explaining that teenager needs for information and skills to protect their reproduction health, the global community has taken a series of steps to build a policy framework for education. Education must be done both at school and at the community level.

Understanding of reproduction health in adolescents was still low, this was based on the highest number of violence against children (Pakasi \& Reni, 2013) which caused in the lack of protection and knowledge of teenager related to sexual violence which results in many underage teenagers being victims. The low level of knowledge about reproduction health for teenagers can have an impact on free sex, marriage at a young age, and can become victims or perpetrators of sexual violence. Sexual violence against children continues to increase, in Bengkulu province recorded cases of sexual violence against women and children increased by $300 \%$ between the period of 2010 to 2011, which is from 133 people to 422 people. In 2013 the number of victims of sexual violence increased to 655 people (Komnas Perempuan, 2013). Data on sexual violence against children and women throughout 2016 until September 2017 experienced a significant increase. From a total of 105 cases of sexual violence consisting of 77 cases in 2016 and 28 cases in 2017, all of which were sexual violence for minors from the data, there were 90\% of victims of sexual violence (Bengkulu Ekspres 8/11/17).

The importance of the process of education in the family to overcome the problem of low understanding of reproduction health. The function of education in the family must be done to create harmony both within and outside the family. (Helmawati, 2014; Tafsir, 2008; Andayani \& Afiatin, 1996; Sudjana, 1994). According to Hanum (2013), family environments that are full of love, mutual help, and warm relationships with each other have a big contribution in shaping children's personalities with positive characters so that the communication role of parents' information on children with all the complex contents and strategies inherent with it being very important. Interactions with parents in 
childhood influence individual personality development that is consistent and their psychological adaptation skills (Körük, at al., 2016). Afiah \& Purnamasari, (2007) explained that the condition of family harmony can help to form a negative attitude in teenagers to premarital sex. The process of education in the family is one of the functions of the family.

Parenting as the closest environment for teenagers is seen as influencing the maturation of self-esteem in teenagers, teenage as a period of self-identity formation is very easily influenced by the environment. Desmiyanti (2015) shows that the role of parental communication in the family is the dominant factor associated with early marriage, so parents can increase their support and care for the younger generation to be better in the future. Providing information about reproduction health from parents is so important, this is supported by Oktiva \& Muhlisin (2017) that there is a relationship between teenager knowledge about reproduction health about pregnancy, childbirth, health review, and avoidance of free sex.

Communication built in the family as an effort to provide education, not only instills values and morals, but also conveys knowledge about sex which is considered taboo for some parents and society in general. Education on matters which are considered taboo from parents to children is an indicator of family harmony through the parenting program. Parenting was an effort to provide information, transfer knowledge about parenting patterns so that the function of education in the family can be realized. This research was expected to be effective for the process of parenting education, as a model of parenting education in order to improve students' understanding of reproduction health. The mindset in this study was presented in Figure 1.

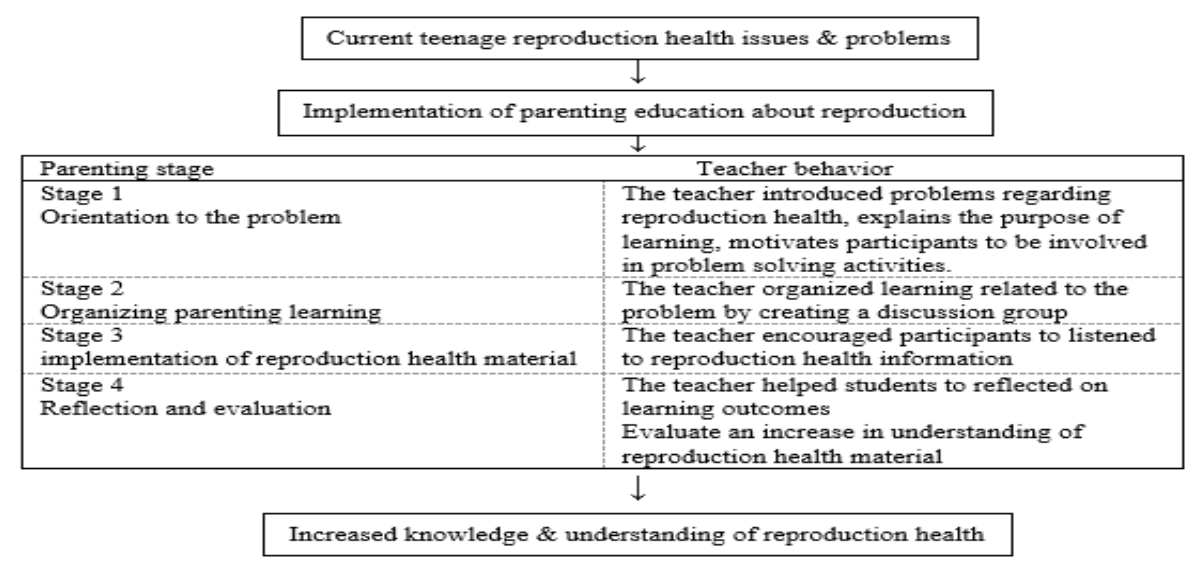

Figure 1

The framework for implementation of parenting to improve reproduction health knowledge.

Aspects of reproduction health knowledge in this study are presented in table 1, formulated as follows. 
Table 1

The number of students attending culture courses

\begin{tabular}{ll}
\hline No & Knowledge aspects of reproduction health \\
\hline 1 & Knowledge of teenager growth and development \\
2 & Knowledge of pregnancy \\
3 & Knowledge of sex education \\
4 & Knowledge of infectious diseases \\
\hline (adapted from Irianto, 2015)
\end{tabular}

The purpose of this study is to apply arenting as an effort to increased the role of parents and teachers as a sourced of information about reproduction health for teenagers by providing them with the right knowledge about reproduction health through parenting classes. It was expected that the parenting program would be useful for teachers to be applied in increased the reproduction health knowledge of high school students. Based on the study of theory and findings of the problem, this researched question was how the effectiveness of parenting can improve the mastery of reproduction health knowledge for Private Vocational School 6 Muhammadiyah Lebong Utara, Lebong, Bengkulu, Indonesia.

\section{METHOD}

\section{Research Design}

This research used a quasi - experimental research and pre test nonequivalent control group design, selection of the design to determine the effectiveness of applying parenting models compared to conventional models. The population of research was the second semester of Private Vocational School 6 Muhammadiyah Lebong Utara, Lebong, Bengkulu, Indonesia. in the academic year 2017/2018. The sample was composed of 70 students divided into two classes, taken by cluster random sampling technique. The one class was experimental groups by applying theparenting model and the remaining class was the conventional class, which was used as the control group.

Table 2

Design pretest posttest non equivalen control group

\begin{tabular}{llll}
\hline Group & Pretest & Treatment & Posttest \\
\hline Experiment & $\mathrm{O}_{1}$ & $\mathrm{X}_{1}$ & $\mathrm{O}_{2}$ \\
\hline Control & $\mathrm{O}_{1}$ & $\mathrm{X}_{0}$ & $\mathrm{O}_{2}$ \\
\hline
\end{tabular}

Information:

$\mathrm{O}_{1}$ : Pre-test of reproduction health knowledge

$\mathrm{O}_{2}$ : Post-test of reproduction health knowledge

$\mathrm{X}_{1}$ : parenting model

$\mathrm{X}_{0}$ : Conventional model

The research was conducted for three months, starting from May to June 2018. The implementation of the parenting model was based on the stages of the procedure. The classes are held weekly meetings with 120 minutes for each meeting. The stages of parenting programs to improve the reproduction health of students are presented in table 3 below. 
Table 3

Stages of the parenting programs to improve the reproduction health knowledge of student

\begin{tabular}{ll}
\hline Parenting stage & \multicolumn{1}{c}{ Teacher behavior } \\
\hline Stage 1 & The teacher introduced problems regarding reproduction \\
Orientation to the problem & $\begin{array}{l}\text { health, explained the purpose of learning, motivated } \\
\text { participants to be involved in problem solving activities. } \\
\text { The teacher organized learning related to the problem by } \\
\text { creating a discussion group } \\
\text { Stage 2 }\end{array}$ \\
$\begin{array}{l}\text { The teacher encouraged participants to listened } \\
\text { Stage 3 } \\
\text { implementation of reproduction } \\
\text { health material } \\
\text { Stage 4 }\end{array}$ & $\begin{array}{l}\text { reproduction health information } \\
\text { Reflection and evaluation }\end{array}$ \\
& $\begin{array}{l}\text { The teacher helped students to reflect on learning outcomes } \\
\text { Evaluating an increased in understanding of reproduction } \\
\text { health material }\end{array}$ \\
\hline
\end{tabular}

\section{Data Collection and Analysis}

The data was collected from the testing scores test of reproduction health knowledge. There was 4 meetings in applied parenting. Each meeting was given a pretest before treatment and ends posttest after treatment with parenting. A total of 12 test items were used in the form of an essay. The tests were made by the researchers and validated by four education experts. The score of the essay answer was between 0,1 and 2. Analysis of validity was used to determine whether or not the test item for reproduction health knowledge was valid. All the test items were valid $(p<0.05)$ are presented in table 4 below.

Table 4

Results of validity reproduction health knowledge test instruments

\begin{tabular}{lll}
\hline Item & Score & Explanation \\
\hline 1 & .874 & Valid \\
2 & .726 & Valid \\
3 & .878 & Valid \\
4 & .759 & Valid \\
5 & .507 & Valid \\
6 & .827 & Valid \\
7 & .276 & Valid \\
8 & .435 & Valid \\
9 & .906 & Valid \\
10 & .414 & Valid \\
11 & .868 & Valid \\
12 & .620 & Valid \\
\hline
\end{tabular}

The coefficient of the Cronbach's alpha test was .917. So the reliability value is high (Sarwono, 2015). The instrument grille of aspects, and reproduction health knowledge indicators presents as follows. 
Table 5

The grids for reproduction health knowledge test instrument

\begin{tabular}{lll}
\hline Aspect & Indicators & Item \\
\hline $\begin{array}{l}\text { Knowledge of adolescent growth } \\
\text { and development }\end{array}$ & $\begin{array}{l}\text { Physical or psychological changes, } \\
\text { fertile period }\end{array}$ & $1,2,3$ \\
Knowledge of pregnancy & $\begin{array}{l}\text { Ideal age for pregnancy, danger of } \\
\text { becoming pregnant at a young age, } \\
\text { abortion }\end{array}$ & $4,5,6$ \\
& $\begin{array}{l}\text { The meaning of sex, sexual behavior, } \\
\text { Sexual violence }\end{array}$ & $7,8,9$ \\
Knowledge of sex education & HIV & $10,11,12$ \\
\hline
\end{tabular}

The data were analyzed by using the T-test to determine significant differences between the two experimental and control classes based on the application of parenting. prerequisite tests were perfomed to determine the normality and homogeneity of the data variance. The resulth of the Kolmogorov-Smirnov One-Sample test, both pre-test and post-test had significant values, $\mathrm{p}=.228>.05$ so that the scores of both tests were normally distributed. Based on the homogeneity test, Levene test, the significant value for the pretest was .400 and the significant value for the post-test was .286. Thus, the scores of both tests had homogeneous variance $(p>.05)$. The result of normality and homogeneity test has been fulfilled the parametric test assumption, which requires the normally distributed data and it has homogeneous variance prior to the use of ANOVAThe data analysis was performed on Statistical Package for Social Sciences (SPSS) for Windows version 22.

\section{FINDINGS}

The results of the reproduction health knowledge test show that the scores of the pre-test and post-test of the conventional class were the lowest, while the parenting class had the highest pretest and post-test scores. The conventional class had an average pre-test score of 9.3714 and post-test of 12.2571 , while the parenting class had 10.6857 for the pretest and 19.6000 for the post-test (Table 5).

Table 6

The results of the reproduction health knowledge test, the scores of the pre-test and posttest

\begin{tabular}{llcccc}
\hline Model & $\mathrm{N}$ & Pretest & \multicolumn{3}{c}{ Posttest } \\
\cline { 3 - 6 } & & Mean & Std. Error & Mean & Std.Error \\
Parenting & 35 & 10.6857 & .39486 & 19.6000 & .27865 \\
Conventional & 35 & 9.3714 & .45297 & 12.2571 & .58171 \\
\hline
\end{tabular}


Table 7

ANOVA summary

\begin{tabular}{|c|c|c|c|c|c|c|}
\hline & & $\begin{array}{l}\text { Sum of } \\
\text { Squares }\end{array}$ & $\mathrm{df}$ & $\begin{array}{l}\text { Mean } \\
\text { Square } \\
\end{array}$ & $\mathrm{F}$ & Sig. \\
\hline \multirow[t]{2}{*}{ Pretest } & Between Groups & 30.229 & 1 & 30.229 & \multirow{2}{*}{4.784} & \multirow{2}{*}{.032} \\
\hline & Within Groups & 429.714 & 68 & 6.319 & & \\
\hline \multirow[t]{2}{*}{ Posttest } & Between Groups & 943.557 & 1 & 943.557 & \multirow{2}{*}{129.598} & \multirow{2}{*}{.000} \\
\hline & Within Groups & 495.086 & 68 & 7.281 & & \\
\hline
\end{tabular}

The result of ANOVA (Table 6) show that the parenting model and conventional model have a significant different mean score, so that the results of this research indicate that there is an effect of the implementation of the parenting model toward the improvement of students' reproduction health knowledge $(\mathrm{F}=129.598, \mathrm{p}=.000<.05)$.

\section{DISCUSSION}

Based on the results of research, the implementation of parenting models has a significant effect on the improvement of students' understanding of reproduction health. According to the results of this research, the mean score of the students' understanding of reproduction health increased which can be shown from average pretest value, 10.685 to value posttest, 19.600. This result can be caused by the effect of the development of students' understanding of reproduction health that can contribute to the development of their parenting education process. This is supported by the results of research by Madani (2003) and Vesely at al., (2014) which state that sex education is an effort to teach, awareness, and information about sexual problems given to children since he understood the problems relating to sex, instincts, and marriage, besides the importance of culture in developing parenting patterns and the development of computer-assisted strategies and teaching materials for teenager reproduction health for junior high school biology teachers as an effort to provide teenagers with the right sources of reproduction health informations. The culture in developing parenting patterns is so important.

In this cultural process, children awaken to maintain their purity, protect themselves from the opposite sex, remembering that they have matured sexually: meaning that if there is sexual intercourse, it is not impossible to have a pregnancy (Rokhmah, 2015). Therefore children need to be careful in their relationships with the opposite sex in order to maintain their purity (Suardiman, 2012). Parents are individuals who encourage all aspects of a child's growth, choose, protect, and demand new life through development programs (Brooks, 2011). Therefore, parents have a great duty and responsibility to support child development in carrying out the right parenting process.

Parenting as an educational effort carried out by the family by utilizing the resources which are available in the family and environment in the form of independent learning activities. Parenting as a complex process is also influenced by various factors both from the parents and children. The three main influences on the child care process are the characteristics and individuality of the child, personal history and psychological resources of the parent, and the context of pressure and support (Brooks, 2011). 
In the parents, the factors that influence the parenting process are personality, beliefs, knowledge, gender, and development history or their childhood. Whereas in children, the factors that influence the parenting process are temperance, gender, ability and age of the child. The absence of parents from the children life, can cause damaging effects on the welfare of children (Ferraro at al, 2016). The characteristics of parents which include the history of parents development, experiences in childhood and beliefs also contribute to the parenting process. The history of parents development when childhood will affect how parents care for their children.

According to Erlanti at al., (2016), parents can expand their knowledge and skills in parenting through educational parenting programs. Parenting education seeks to improve or facilitate the behavior of parents who will influence the positive results of development in their children. Parenting education explains various teaching and support programs that focus on the skills, feelings, and tasks of being a parent.

\section{CONCLUSSION AND SUGGESTIONS}

Based on the results of this research, it is concluded that the implementation of parenting models on sex education has a significant different effect based on the increase in pretest and posttest scores so that students improve their understanding of reproduction health. Students' knowledge about sexuality and reproduction health is so important to prevent free sex, young marriages, and victims of sexual violence. Increasing the role of parents and teachers can be done by making regular meetings (a kind of parenting class) for them. The importance of sex education for parents is an effort to provide information, transfer knowledge about parenting patterns so that the function of education in the family can be realized. Programs that promote access and use of teenagers reproduction health services are most effective when the parenting approach is combined with community acceptance. The suggestions based on the results of this study are that more research is needed to determine the best way to provide reproduction health services, especially for vulnerable and marginalized populations.

\section{REFERENCES}

Afiah, F. N., \& Purnamasari, S. E. (2007). Hubungan antara keharmonisan keluarga dengan sikap terhadap seks pranikah pada remaja. Jurnal Psikologi Perkembangan. Retrived from : http://fpsi.mercubuana-yogya.ac.id.

Andayani, B \& Afiatin, T. (1996). Konsep diri, Harga Diri dan Kepercayaan Diri Remaja. Jurnal Psikologi. Retrieved from http://ilib.ugm.ac.id/jurnal/detail.php?dataId=4105

Bengkulu Exspres. Kasus Kekerasan Terhadap Anak dan Perempuans. November 2017. Editor, 24, 1-2.

Brooks, J. (2004). The Process of Parenting (Sixth Edition). New York: McGraw-Hill.

Brooks, J. (2011). The Process of parenting. (Terjemahan Rahmat Fajar) Yogyakarta: Pustaka Pelajar (Edisi Asli diterbitkan tahun 2011 oleh McGrow-Hill. New York). 
Denno, D.M., Hoopes, A.J \& Venkatraman, C.M. (2014). Effective Strategies to Provide Adolescent Sexual and Reproduction Health Services and to Increase Demand and Community Support. Journal of Adolescent Health, 56, 22-41.

Erlanti, M. S., Nandang, M., \& Hery, W. (2016). Tekhnik Parenting dan Pengasuhan Anak Studi Deskriptif Penerapan Tekhnik Parenting di Rumah Yayasan Cahaya Insan Pratama Bandung. Prosiding KS: Riset \& PKM. 3(2). Retrievedfrom jurnal.unpad.ac.id/prosiding/article/download/13648/6486

Ferraro, A. J., Malespin, T., Oehme, K., Bruker, M., \& Opel, A. (2016). Advancing coparenting education: Toward a foundation for supporting positive post-divorce adjustment. Child and Adolescent Social Work Journal, 33(5), 407-415. Retirved from: https://www.he.k-state.edu/fshs/people/aferraro/aferraro.pdf.

Haberland, N \& Rogow, D. (2015). Sexuality Education: Emerging Trends in Evidence and Practice. Journal of Adolescent Health,(56) 15-21.

Hanum, F dkk. (2013). Pengembangan Karakter Anak . Universitas Negeri Yogyakarta. Yogyakarta.

Helmawati. (2014). Pendidikan keluarga. Bandung: PT Remaja Rosdokarya Offset.

Irianto, K. (2015). Kesehatan Reproduksi Teori \& Praktikum. Bandung: Alfabeta.

Jacob, G. (2006).Cooperatif Learning: Theory, Priciples, and Techniques. JF New Paradigma Educaion.

Komnas Perempuan. 2013. Kegentingan Kekerasan Seksual: Lemahnya Upaya Penanganan Negara Catatan Kekerasan Terhadap Perempuan. Jakarta, 7 Maret 2014

Körük, S., Öztürk, A., \& Kara, A. (2016). The Predictive Strength of Perceived Parenting and Parental Attachment Styles on Psychological Symptoms among Turkish University Students1. International Journal of Instruction,9(2). 1694-609X

Madani, Y. (2003). Pendidikan Seks Untuk Anak Dalam Islam. Jakarta: Pustaka Zahra.

Morris,J.L., \& Rushwan, H. (2015). Adolescent sexual and reproduction health: The global challenges. International Journal of Gynecology and Obstetrics, 131 (2015) 4042

Muhammad, K. 1996. Prioritas pelayanan kesehatan reproduksi dalam seksualitas kesehatan reproduksi dan ketimpangan gender. Yogyakata: Pustaka sinar harapan.

Oktiva, Y D \& Muhlisin, A. (2017). Hubungan Antara Tingkat Pengetahuan Tentang Kesehatan Reproduksi Remaja Dan Pola Asuh Orang Tua Dengan Sikap Remaja Tentang Seks Bebas Di Sma N 1 Tawangsari Sukoharjo. Jurnal Berita Ilmu Keperawatan,52-61

Pakasi, D. N \& Reni, K. (2013). Antara Kebutuhan dan Tabu: Pendidikan Seksualitas dan Kesehatan Reproduksi bagi Remaja di SMA. Jurnal Makara Seri Kesehatan, 17(2): 79-87. DOI: 10.7454/msk.v17i2.xxxx. 
Rokhmah, D. (2015). Pola Asuh dan Pembentukan Perilaku Seksual Berisiko Terhadap Hiv/Aids Pada Waria. Jurnal Kesehatan Masyarakat. 11 (I) (2015) 125-134.

Sarwono, J. (2015). SPSS 22. Yogyakarta: Penerbit ANDI.

Suardiman, S.P. (2012). pacara Tarapan dalam Budaya Jawa (Suatu Kajian Pendidikan dalam Upaya Pelestarian Kearifan Lokal). Laporan Penelitian. LPPM UNY.

Sudjana, J. (1994). Peranan Keluarga di Lingkungan Masyarakat. Bandung: Remaja Rosdakarya.

Tafsir, A. (2008). lsafat Pendidikan Islami Integrasi Jasmani, Rohani dan Kalbu Memanusiakan Manusia. Bandung: Remaja Rosdakarya.

Vesely, C. K., Ewaida, M., \& Anderson, E. A. (2014). Cultural competence of parenting education programs used by Latino families: A review. Hispanic Journal of Behavioral Sciences, 36(1), 27-47

William. C. (2014). Teori Perkembangan, Konsep dan Aplikasi. Yogyakarta : Pustaka Pelajar. 